\title{
The Readiness of Batik Banyumas in the Era of China-ASEAN Free Trade Area (CAFTA)
}

\author{
Sri Wijayanti, Nuriyeni K. Bintarsari \\ Department of International Relations, Jenderal Soedirman University \\ J1. HR. Bunyamin Purwokerto, Indonesia \\ yantietaslim@yahoo.com
}

\begin{abstract}
Free trade agreement between China and Association of Southeast Asia Nations (ASEAN) will enable goods from China to easily enter ASEAN's market and vice versa. Those products will be available in ASEAN's market, especially in textile industries. Indonesia is one of the countries agreed on an agreement to receive products from China in its market. One of the local products in Indonesia that have to compete in the free market is Batik Banyumas, which is one of Banyumas County products. This article will discuss on the opportunities and challenges faced by Batik Banyumas in China - ASEAN free trade area or known as CAFTA. Data obtained in this article were the results of research carried out in 2012. This research found out that Batik Banyumas is originated only in its pattern, whilst the fabric and inks used in the production are imported from China. The research conductedusing qualitative method.
\end{abstract}

Keywords: Batik Banyumas, CAFTA, Regionalism

\section{Introduction}

Southeast Asia Countries had signed aFramework Agreement on Economic Cooperationlegalized during the 8th ASEAN Summit Meeting held in Phnom Penh, Cambodia, in 2002.The agreement established an arrangementto initiate formation of a free market.The Framework agreement discussed on the deduction and the annulment of tax for certain goods agreed on in the framework. The arrangement implies that since 2010 in ASEAN countries such as: Thailand, Malaysia, Indonesia, Singapore and Philippine, there will be 7306 tariff posts being the subject of zero tax policy (Ibrahim, Ika and Ari, 2010). The arrangement implies that all goods listed in the agreement will be subjected to 0 (zero) rupiah tax charge. Tax annulment will implies in the easy entrance access of goods from countries bound by the agreement, and local products will have to compete with foreign products in the free market.CAFTA will integrate no less than 1,91 billion people; consists of 1,3 billion people from People's Republic of China and 610 million people from ASEAN countries (knowledge.wharton.upenn.edu).
Textile is one of the products being agreed on in the CAFTA agreement. Since CAFTA enactment, products from China, mainly textiles, has flooded trade centres and markets, traditional and modern markets alike.In Indonesia for example, in Tanah Abang and Rawa Badak markets, most vendors will be selling garments from China embossed with batik printing on it in very reasonable price, approximately 35-50 thousand rupiah per piece (kabarbisnis.com).In the Tanah Abang wholesaler market, China produced batiks are dominating batik market from wholesale to retail buyer (Sudiarto, 2011). Foreign batik products which are available abundantly in national and local markets, have potentially threaten local batik existence.

Banyumas County is one of the county that produced local batik in Southern part of Java. Compared to other counties nearby, Batik Banyumas is considered still exist today. It can be seen by the number of Batik's shop owner in Banyumas, who are still producing Banyumas'sbatik nowadays. In other counties nearby, the number of Batik's shop owner (perajin) and the number of Batik workers (pengobeng) are very few, in some cases they do not 
prevail anymore. Banyumas county approximately has 43 Batik's shop owner (perajin) and 456 workers/pengobeng, and most of them are female (Disperindagkop, 2010). In the Batik's industry technical term, pengobeng or worker refers to female batik painters and owner or perajin refers to person who orders batik from the workers and sell batik in their shops. Usually, batik's shop owners are small scale businessmen with limited amount of capital.Batik Banyumas is considered as one of local asset which also serves as Banyumas's identity, but in today's market, Batik Banyumas must compete with China produced batik as the impact of trade liberalisation. This article will discuss on the readiness of Batik Banyumas in dealing with ChinaASEAN Free Trade Area (CAFTA).

\section{Method}

The subject of the previous research is small scale batik's shop owners and female batik painters in Banyumas county. They are mostly reside in the sub district (kecamatan) areas, such as in Banyumas, Sokaraja, and Patikraja sub districts. The research was conducted using qualitative method, instruments used in the research including in-depth interviews; participant observations and literatures studies. Interactive analysis model is the analytical model used in the research.

\section{Discussion}

\subsection{Regional Cooperation}

Interconnectivitiy between states creates economical interdependency and in the end this condition leads to certain changes in nation state's economy and security relations. In the era of globalisation, one of the palpable change is the increasing activity of regional economic cooperation.
Regionalism is defined as a region where nation states have physical closeness in term of geographical location (Raymo Varynen, 2003). This definitionis challenged by the fact that physical borders becomes irrelevant as nation states increase their economic interconnectivity, and this will enable national economy activities to be directly linked with international economic trends. As we can see in the establishment of several free trade areas in certain regions. Regionalism makes it possible for states to create and maintain free trade (L. Alan winters, 1996). In a free trade area involving several states, there will be certain changes in their social political conditions because they have to adjust to the free trade mechanisms. Regionalism also serves as a way to integrate national-international economy and to pave ways for national economy to survive in the global system (Helen E S Nesadurai, 2002). Globalisation enforced governments in the world to integrate their national industries into global economic system, to maintain their survivability in the global competition. This is the principal concept known as regionalism developmentalism which can be described as:

"Developmental regionalism encapsulates the developmental state idea of state intervention in markets to promote national development agendas, in this case by adopting an approach to regionalism through which to nurture emerging domestic firms to eventually become internationally competitive." (Helen E.S Nesadurai, 2002 : 5)

\subsection{The Readiness of Batik Banyumas in the Era of CAFTA}

China-ASEAN Free Trade Area (CAFTA) was established in 2002 by the tenth members of ASEAN and the People's Republic of China. CAFTA is an agreement between ASEAN and China to form a free 
trade area by decreasing and eliminating trade impediments such as tax and tariffs, increasing access of service markets, and stimulating economic growth within CAFTA countries. The main idea of CAFTA is to form a single market between ASEAN countries and China.

Indonesia is one of the country that signed the CAFTA agreement, it means all provinces and counties in Indonesia are subject of CAFTA market. Banyumas County as part of Indonesia also has to prepare itself to compete in the free market. One of the main concern in Banyumas is the competition between Batik Banyumas and China produced batiks, which available abundantly in local markets (The Jakarta Post, 2010 ). Affordable price, varieties of patterns, and great quantity of supplies of China produced batiks challenged the existence of Batik Banyumas. Research shows that the relations between China and Banyumas in textile industry is very intense. Batik's industries in Banyumas are very dependent on the supplies of white cotton fabrics (kain mori)and Batik's inks (malam) imported from China.Indonesia imported white cotton fabrics from China because they are cheaper than to imports them from Brazil.In a year after CAFTA's implementation, the batik's shop owners in Banyumas stated that their batik orders were not decreasing significantly. The evidence based on the interview with Ella, owner of batik's shop 'NUR', that said that the selling of Batik Banyumas is generally steady and during Banyumas County Day the selling will be slightly increasing. Based on that fact, it can be concluded that Banyumas's batik has its own market segmentation. However, the shop owners complained aboutuprising price of white cotton fabrics and inks used in the batik making, they said the price went up since last year. Based on the statement from Ahmad Djawahir, one of the chairman in Batik Banyumas board committee, the price of white cotton fabrics in 2010 was 7.450 rupiah per yard and in 2011, the price was 8.900 rupiah per yard. These fabrics were imported from China. In general, the price of a piece of white cotton fabric to be print into one batik is 25.000-30.000 rupiah this year, compared to last year which was only 10.000-15.000 rupiah per piece for one batik.Other owner also said that the price for prime white cotton fabrics (kain prima) in 2011 was 200.000 rupiah per piece (33 yards) and this year the price also went up. The increasing price for inks was around 15.000 rupiah, from 10.000 rupiah to 25.000 rupiah in 2011.

Banyumas Country authorities had implemented a policy for civil servants in Banyumas to wear Batik Banyumas as an obligation. This policy proves to be quite effective to ensure that Batik Banyumas will prevail against China produced batiks. Banyumas's authorities also urges all residents in the county to be proud to wear batik, especially Banyumas Batik, not only during formal events but also in their informal events. During Banyumas county's day, the Banyumas people will celebrate it by wearing Batik Banyumas. The authorities and batik's businessmen also held several exhibition on batik and educated people on the varieties of batik patterns and the value in preservingBatik Banyumas as their local identity.

Special characteristic embedded in Batik Banyumas are their unique colours and patterns. Unlike batik from Solo and Yogyakarta who are having basic colour choices such as white, brown or light brown. Batik Banyumas is more colourful, has bold colour base and unique patterns as different from other batik produces by other counties, therefore this particular batik has very loyal consumers. 


\section{Conclusion}

Batik Banyumas is considered as a cultural inheritance that needs to be preserved. The industry of Banyumas's batik also a productive industry where hundreds of people depend on it as their main income, especially in some sub districts such as Sokaraja, Patikraja and Banyumas. In the CAFTA era, Batik Banyumas must compete with China produced batiks, which are not only cheaper but also abundant in supply and patterns. The previous research shown that despite having loyal consumers, Batik Banyumas producents still facing problem of uprising price of imported fabrics and inks from China.This condition eventually lead to batik's price, where China produced batiks are cheaper than Batik Banyumas. By and large, the Banyumas County authorities should ensure that Batik Banyumas industry as local products and cultural inheritance will prevail in the free market era.

\section{References}

1) Dinas Perdagangan, Perindustrian dan Koperasi, 2010. Numbers of Perajin and Pengobeng in Banyumas County.Framework Agreement on Economic Cooperation Between ASEAN and The People's Republic of China, 2002 (http://wits.worldbank.org/GPTAD/PDF/archive/ ASEAN-China.pdf)Accessed onMay 282014

2) Ibrahim, Ika, Permata Meily and Ari, WibowoWahyu, (2010). Dampak Pelaksanaan ACFTA Terhadap Perdagangan Internasional Indonesia (The Implication of ACFTA Implementation on the international trade), Buletin Ekonomi Moneterdan Perbankan, July (http://blog.umy.ac.id/ghea/files/2011/12/dampakpelaksanaan-acfta-terhadap-perdaganganinternasional-indonesia.pdf). Accessed on May 30 2014
3) Kabarbisnis.com. (2010).SerbuanProduk China, Bagaikan Air Bah(China's products flooded local markets).(http://kabarbisnis.com/read/289314/)Ac cessed on April 292014

4) Nesadurai, S. (2002). Attempting Developmental Regionalism Through AFTA: The Domestic Politics - Domestic Capital Nexus ,Institute of Defence and Strategic Studies Singapore (31), August 2002. (ftp://ftp.icesedu.co/ cramirez/ Versionados/bloques/S05.Integracion\%20regional $\% 20 \mathrm{y} \% 20$ globalizacion/Regionalism\%20versus\% 20multilaterism.pdf). Accessed on May 302014

5) Sudiarto. Nasib Industri Batik dalam Pasang Naik Individualisme (Batik industries in the Rising Tide of Individualism). (http://interseksi.org/ blog/files/nasib_batik.php) Accessed on April 29 2014

6) thejakartapost.com. (2010). ACFTA help the country's economy grow but... February 2. (http://www.thejakartapost.com/news/2010/02/02/ acfta-help-country039s-economy-grow.html)

Accessed on May 302014

7) Vayrynen, Raimo. (2003). Regionalism: Old and New. International Studies Review(5), 2551(http://www.wiso.uni-hamburg.de/uploads/ media/11_Vaerynen_2003.pdf)AccessedonMay 30 2014Winters, L. Alan, Regionalism versus Multilateralism. The World Bank Washington, D.C (ftp://ftp.icesi.edu.co/cramirez/Versionados/ bloques/S05.Integracion\%20regional\%20y\%20gl obalizacion/Regionalism\%20versus\%20multilater ism.pdf) Accessed on May 302014

8) Will an Integrated ASEAN Region Challenge China? Jan 15, 2014, (https://knowledge.wharton.upenn.edu/article/will -an-integrated-asean-region-challenge-china/).

Accessed on April 282014 